\title{
Efficacy of Agavesisalana n-Hexane Extract in the Control of Callosobruchus maculatus (Fabricius) (Colloptera: Bruchidae) Pest
}

\author{
Chrinius Hammuel ${ }^{*}$, Musa Mohammed, Olalekan Babatunde Adesina, Usman Jajere Mohammed, Eprhaim Akuaden \\ Audu, Suleiman Bala
}

Department of Basic Research, National Research Institute for Chemical Technology, Zaria.

\begin{tabular}{|c|c|}
\hline ARTICLE INFO & ABSTRACT \\
\hline Article history: & \multirow{6}{*}{$\begin{array}{l}\text { Collosobruchus maculatus is a weevil that has been causing great damage to cowpeas especially in the stores. } \\
\text { Therefore, there is need to search for biopesticides that can be used to control the pest rather than using synthetic } \\
\text { chemicals. In this work different concentrations of Agave sisilana n-hexane extract were prepared using two-fold } \\
\text { dilution at } 100,50,25,12.5,6.25,3.125 \text { and } 1.5625 \mathrm{mg} / \mathrm{ml} \text { and were used to treat } 40 \text { selected beans in different } \\
\text { kilner jars. The treated beans were infested with ten }(10) \text { identified female and male } C \text {. mauculatus each. The } \\
\text { result shows that the insect was more killed by the extract at concentration greater than } 50 \mathrm{mg} / \mathrm{ml} \text {. The plant } \\
\text { extract was effective against the oviposition and survival of larvae and pupae when compared with the untreated } \\
\text { control. In conclusion, the extract of has great potential for use as a plant-based biopesticide for controlling } C \text {. } \\
\text { maculatus. }\end{array}$} \\
\hline Received on: $15 / 07 / 2015$ & \\
\hline Revised on: $23 / 07 / 2015$ & \\
\hline Accepted on: $16 / 08 / 2015$ & \\
\hline Available online: $24 / 08 / 2015$ & \\
\hline $\begin{array}{l}\text { Key words: } \\
\text { A. sisilana, Biopesticide, C. } \\
\text { maculatus, and Oviposition. }\end{array}$ & \\
\hline
\end{tabular}

\section{INTRODUCTION}

Callosobruchus maculatus is a cosmopolitan pest that infests a wide range of stored cowpeas including beans. This insect is one of the most damaging pests of the kidney bean in the tropical and subtropical environment [1]. It causes losses of up to $30 \%$ of stored beans. Its oviposition and growth are continuous, and the larvae feed on the seeds. After emergence from the seeds, the adults reproduce either in the field or in the stored seeds in a continuous cycle [2]. Larvae reduce product quality by their presence and by the production of frass and webbing, and they also cause direct damage by feeding [3].

The insect pests cause great damage to crops both in the field and in stores. They have normally been causing great challenge to farmers. The effect of pest on Agricultural products can lead to food scarcity. Muthomi et al., [4] reported that many people in developing countries engaged in Agriculture but with low productivity because of diseases and insect pests' damage. Researchers have reported that grain damage could reach 100 per cent if the insects are not controlled. The serious damage caused to the grain by the pest has led to extensive use of synthetic insecticides to control it [5]. There is a need to protect our crops from pests/insects damage so that there will be food availability. Weevils especially those from the beans (Callosobruchus maculatus) have been reducing the quality of the crop for consumption or for commercial purposes.

* Corresponding Author

Email: chris2012bansi@gmail.com

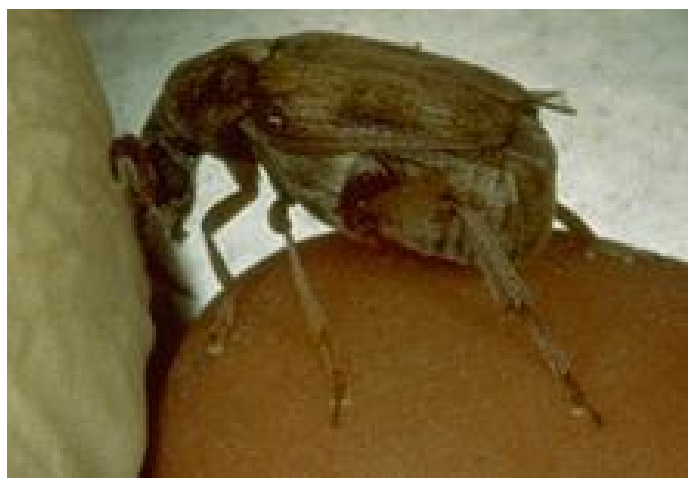

Fig. 1: Male Callosobruch maculates.

The adults do not require food or water and spend their limited lifespan (1-2 weeks) mating and laying eggs on beans. Once inseminated, adult females will lay (oviposit) single fertilized eggs on the external surface of a dry bean seed. Individual eggs $(0.75 \mathrm{~mm}$ long) are oval or spindle shaped, clear, shiny, and firmly glued to the bean surface as seen in figure 3 . The larva that hatches from the egg burrows from the egg through the seed coat and into the bean endosperm where it causes damage to the bean. The adult that results from pupation chews through the seed coat and emerges from the bean. The adults are fully mature 24 to 36 hours after emergence as in figure 1 and 2. Generation time also depends on the host species of bean you choose to use. In this research the generation time range from 5-10 weeks. 


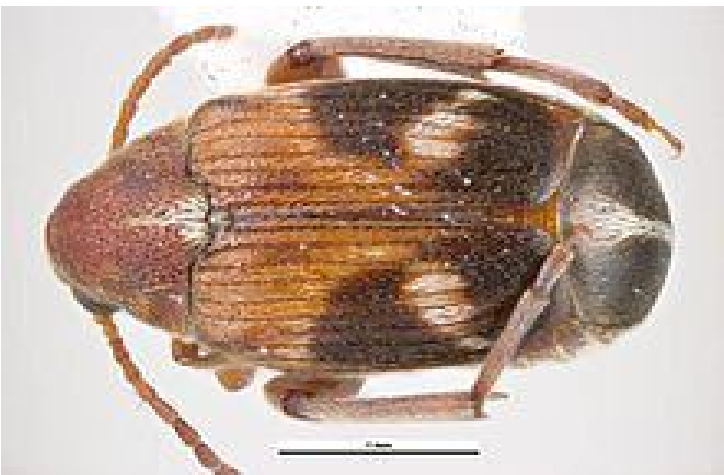

Fig. 2: Female Callosobruch maculates.

The plant, Agave sisalana has been according to literatures reported to have the potential activity against pest. The control of these pests in storage systems mainly depends on chemical produced compounds. However, many alternatives have been tested to replace the chemical compounds for stored product and quarantine uses due to their hazardous effect. The hazards of pesticides are well documented. A recent brief survey of pesticide related articles produced a ratio of over 40 negative for each one with a more positive viewpoint. Some take the line that organic agriculture has survived successfully for centuries and should therefore be the basis of modern productive agriculture. A host of others point to health problems from accidental or deliberate exposure to pesticides.

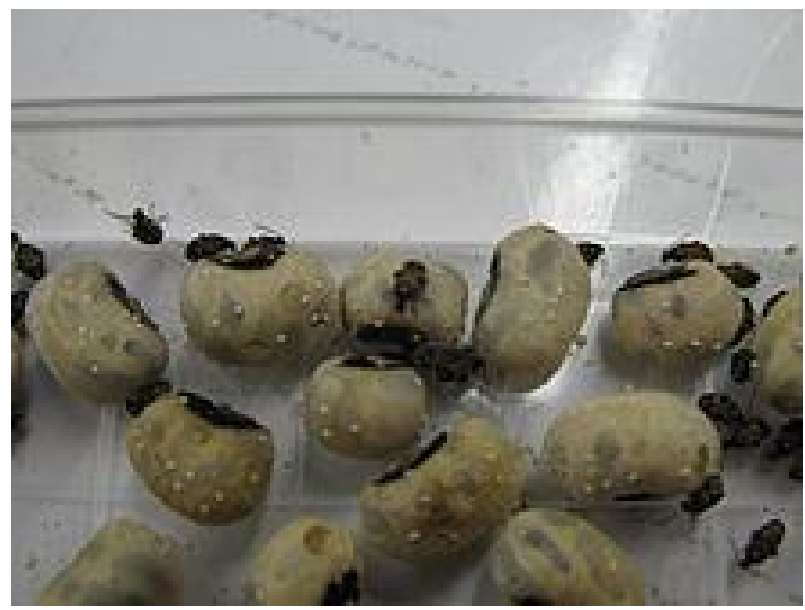

Fig. 3: The damage on black-eye beans.

It is therefore imperative to develop safe alternatives that have the potential to replace the toxic fumigants, yet are effective, economical and convenient to use [6]. One of the ways of reducing the continual dependence on imported insecticides is to use the widely available but underutilized plant products. Many spices and herbs, and their extracts, are known to possess insecticidal properties.

\section{MATERIALS AND METHODS}

\subsection{Collection and preparation of plant sample}

The plant sample was collected from the premises of National Research Institute for Chemical Technology (NARICT),
Zaria and was identified in Bioresources department, NARICT. The sample was sliced into small pieces and dried at room temperature for two weeks. It was grinded into powdered form using pestle and mortar and then $150 \mathrm{~g}$ of the powdered plant sample was weighed and subjected to soxlet extraction using 1000 $\mathrm{cm}^{3}$ methanol and n-hexane solution.

\subsection{The sample of beans, maintenance and preparation}

The beans with the insect (Callosobruchus maculatus) was collected from Samaru market. The unaffected beans seed was obtained from Institute of Agricultural Research, Zaria. The mechanically damaged seeds and those damaged by insects were separated from the unaffected seeds. Then seeds were disinfected using methanol and deep freezer for 72 hours to eliminate any contamination [7]. The seeds were removed from the deep freezer and kept at room temperature and relative temperature to equilibrate and to maintain the moisture content of the seeds [8].

\subsection{Identification of the insects Treatment and Infestation of the bean seeds}

Callosobruchus maculatus was identified in the laboratory based on the sex. Females are darker overall, while males are brown. The plate covering the end of the abdomen is large and dark in colour along the sides in females, and smaller without the dark areas in males). Forty (40) of bean seeds in each of the kilner jars were treated with the extracts and allowed to dry for 30 minutes. The ten (10) of the identified female of $C$. maculatus and ten (10) of the identified male $C$. maculatus were introduced into the kliner jars in duplicates containing the beans treated with the extracts of varying concentrations of $100 \mathrm{mg} / \mathrm{l}, 50$ $\mathrm{mg} / \mathrm{ml}, 25 \mathrm{mg} / \mathrm{ml}, 12.5 \mathrm{mg} / \mathrm{ml}, 6.25 \mathrm{mg} / \mathrm{ml}, 3.125 \mathrm{mg} / \mathrm{ml}$ and $1.5612 \mathrm{mg} / \mathrm{ml}$ using two-fold dilution. The same was done to the kiln jar containing the negative control. The total seeds that were infested with the insects were 40 seeds and ten female and ten males were introduced to each of the kilner jars containing the beans seeds.

\subsection{Culturing and Maintenance of the Insects}

All the kilner jars containing the treated and infested beans were incubated at room temperature under humidity of $31.17 \% \mathrm{RH}$. The treated and infested beans were incubated at 24, 48, 72 and 96 hours and the mortality rate of the insects as a result of effect of the extract after treatment as reported by Raja et al. [9]. The effect of the extract was studied for two weeks to determine the efficacy on the oviposition of the insects. The first filial (F1) and second filial generations were also determined at 35 days and 70 days post treatment.

\section{RESULTS AND DISCUSSION}

The result showed that the insect was killed or inhibited at concentrations of $100,50,25$ and $12.5 \mathrm{mg} / \mathrm{ml}$ than those on the untreated seeds as seen in Table 1. Table 2 shows the effect of the extract on the laying of eggs by the insects for two weeks after 
pos-treatment. That is the extract significantly reduced the oviposition of the $C$. maculatus compared to the untreated seeds.

Table 1: The Mortality count of the insect pest in some interval of time after treatment of the beans.

\begin{tabular}{lllll}
\hline $\begin{array}{l}\text { Concentration } \\
(\mathrm{mg} / \mathrm{mL})\end{array}$ & $\begin{array}{l}\text { Average } \\
\text { number of } \\
\text { deaths at } 24 \\
\text { hours }\end{array}$ & $\begin{array}{l}\text { Average } \\
\text { number of } \\
\text { deaths } 48 \\
\text { hours }\end{array}$ & $\begin{array}{l}\text { Average } \\
\text { number of } \\
\text { deaths at } \\
72 \text { hours }\end{array}$ & $\begin{array}{l}\text { Average } \\
\text { number of } \\
\text { deaths at } \\
96 \text { hours }\end{array}$ \\
\hline 100 & 3 & 3 & 2 & 2 \\
50 & 3 & 2 & 3 & 2 \\
25 & 2 & 2 & 2 & 2 \\
12.5 & 2 & 2 & 2 & 1 \\
6.25 & No death & 3 & 1 & 1 \\
3.125 & No death & 1 & 1 & 1 \\
1.5612 & No death & 1 & 1 & 1 \\
Control & No death & No death & 2 & 2 \\
\hline
\end{tabular}

Table 2: Ovipositional count at two weeks post-treatment, F1 and F2 generation of the insect pest.

\begin{tabular}{llll}
\hline $\begin{array}{l}\text { Concentration } \\
(\mathrm{mg} / \mathrm{mL})\end{array}$ & $\begin{array}{l}\text { Ovipositional } \\
\text { average count }\end{array}$ & $\begin{array}{l}\text { Average } \\
\text { population at } \mathrm{F} 1 \\
\text { generation }\end{array}$ & $\begin{array}{l}\text { Average } \\
\text { population } \\
\text { at F2 } \\
\text { generation }\end{array}$ \\
\hline 100 & 61 & 17 & 27 \\
50 & 121 & 55 & 61 \\
25 & 154 & 63 & 72 \\
12.5 & 161 & 66 & 83 \\
6.25 & 163 & 87 & 91 \\
3.125 & 170 & 90 & 95 \\
1.5612 & 181 & 122 & 130 \\
Control & 192 & 133 & 140 \\
\hline
\end{tabular}

The reduction of the oviposition by the extract was found to be higher on seed treated with higher concentration of the extract $(100 \mathrm{mgl} / \mathrm{ml})$ and lower on seeds treated with lower concentration of the extract $(\leq 50 \mathrm{mg} / \mathrm{ml})$ as seen in Table 2 .

The effectiveness of the Agave sisalana extract may be attributed to the presence of bioactive compounds [5]. The plant extract may impair respiration of the insect as suggested by Hall and Harmann [10] as it blocks the spiracle thereby leading to suffocation. Other insecticidal effect could be attributed to toxicity and repellence by the constituent of the extract [8]. The extract could also modify the micro-environment there by discouraging and probably killing the insect which consequently reduced the number of eggs laid by the insects on treated seed [11]. The extracts coating the seed may have a possible contact of the insect during oviposition since eggs are laid on the seeds and thus the extracts can acts as contacts pesticide to the insect which can penetrate the body and possibly interfering with the normal development of the adult $C$. maculatus by suppressing hormonal and biochemical processes as reported by Abdulllahi, [8].

In conclusion, the plant has proven favourable potency for the controlling of the insect by reducing their numbers. However, there is the need to make further research and it will be very vital to isolate the active compounds in the plant that is, appropriate and affordable technology should be developed.

\section{REFERENCES}

1. Ofuya TI, Olotuah OF, Akinyoade DO. The Effect of Storage on the Efficacy of Eugenia Aromatica (Baill.) in the control of Callosobruchus Maculatus (Fabricius) (Coleoptera: Bruchidae) Pest. Journal of Applied Science Environmental Management. 2010; 14(1): $97-100$.

2. Ayvaz A, Sagdic O, Karaborklu S, Ozturk I. Insecticidal activity of the essential oils from different plants against three stored-product insects. Journal of Insect Science. 2010; 10: 13

3. Johnson JA, Valero KA, Hannel MM. Effect of low temperature storage on survival and reproduction of Indian meal moth (Lepidoptera: Pyralidae). Journal of Crop Protection. 1997; 16: 519523.

4. Muthomi JW, Otieno PE, Chemining'wa GN, Nderitu JH. Effect of Chemical Pesticide Spray on Insect Pests and Yield of Food Grain Legumes. African Crop science conference proceedings. 2007; 8:981-986.

5. Osekre EA, Ayertey IN. Control of the cowpea beetle, Callosobruchus maculatus (F.) (Coleoptera: Bruchidae), on stored cowpea using vegetable oils. Ghana Journal of Agricultural Science. 2002; 35: 103-110.

6. Ayvaz A, Albayrak S, Karaborklu S. Gamma radiation sensitivity of the eggs, larvae and pupae of Indian meal moth Plodia interpunctella (Hübner) (Lepidoptera: Pyralidae). Journal of Pest Management Science. 2008; 64:505-512.

7. Awoyinka OA, Oyewole IO, Amos BMW, Onasoga OF. Comparative pesticidal activity of dichloromethane extracts of Piper nigrum against Sitophilus zeamais and Callosobruchus maculates. 2006; 5 (24), pp. 2446-2449.

8. Abdullahi N. Studies on the Efficacy of Leaf Extract of Balanites aegyptiaca on the Oviposition and Survival of Immature Stages (Larvae and Pupae) of Callasobruchus maculatus (f.) on Treated Cowpea Seed. Bayero Journal of Pure and Applied Sciences. 2011; 4(1): $40-43$.

9. Raja N, Babu A, Dorn S, Ignacimuthu S. Potential of plants for protecting stored pulses from Callosobruchus maculates (Coleoptera: Bruchidae) infestation. Biological Agriculture and Horticulture Journal. 2001; 19(1):19-27.

10. Hall JS, Harman GE. Protection of stored legume seeds against attack by storage fungi and weevils: Mechanisms of action of oil seed treatment. Journal of Crop Protection. 1991; 10: 375-80.

11. Boateng BA, Kusi F. Toxicity of Jatropha seed oil to Callasobruchus maculatus (F) (Coleoptera:Bruchidae) and its parasitoid, Dinarmus basalis (Hymeneptera :Pteromalidae ) Journal of applied Sciences Research. 2008; 4(8):945-951

\section{How to cite this article:}

Chrinius Hammuel, Musa Mohammed, Olalekan Babatunde Adesina, Usman Jajere Mohammed, Eprhaim Akuaden Audu, Suleiman Bala. The Efficacy of Agave Sisalana n- Hexane Extract in the Control of Callosobruchus Maculatus (Fabricius) (Colloptera: Bruchidae) Pest. J App Biol Biotech. 2015; 3 (04): 001-003. 